\title{
Morphological variation in the striped water snake Helicops trivittatus (Gray, 1849) \\ (Reptilia: Serpentes: Xenodontidae) of eastern Amazonia \\ Variação morfométrica da cobra-d'água Helicops trivittatus (Gray, 1849) \\ (Reptilia: Serpentes: Xenodontidae) do leste da Amazônia
}

Douglas Athon Rossman'

\begin{abstract}
Helicops trivittatus, an aquatic snake endemic to eastern Amazonia, has an essentially invariant colour pattern, but it does exhibit sexual and/or individual variation in many meristic and mensural characters. This study is based on a series of 45 preserved specimens.
\end{abstract}

Keywords: Brazil. Serpentes. Xenodontidae. Helicops trivittatus. Variation.

Resumo: Helicops trivittatus, uma cobra aquática endêmica da Amazônia oriental, possui um padrão de coloração essencialmente sem variação, mas apresenta variação sexual e/ou individual em muitos caracteres merísticos e morfométricos. Esse estudo baseia-se em 45 exemplares preservados.

Palavras-chave: Brasil. Serpentes. Xenodontidae. Helicops trivittatus. Variação.

Luther College. Department of Biology. Decorah, lowa, U.S.A. (rossmado@luther.edu).

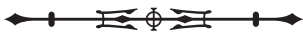




\section{INTRODUCTION}

Helicops trivittatus was described by Gray (1849) as Myron trivittatus in the mistaken belief that this species belonged to that Southeast Asian genus of homalopsid water snakes. The female holotype and a second, male, specimen had been obtained by the British Museum (Natural History) $(\mathrm{BM}(\mathrm{NH}))$ from the Zoological Society of London. The male allegedly came from 'India', while the holotype had no locality data associated with it. The incorrect locality data almost surely contributed to Gray's faulty generic assignment inasmuch as snakes of the xenodontid genus Helicops do bear a striking external resemblance to some of the homalopsid genera, especially Enhydris (see Rossman \& Scott, 1968, for a case in which a specimen of Enhydris plumbea - erroneously labeled as originating in Costa Rica - was described as a new species of Helicops!).

Having subsequently obtained juvenile specimens from Pará, Brazil, Boulenger (1893) correctly assigned Gray's species to the genus Helicops. He also provided an excellent illustration of the head, neck, and venter, as well as giving a concise description and basic scale counts for the four specimens in the British Museum. Gomes (1918) provided basic scale data for four additional specimens from Pará in the Museu Paraense, Belém. The next author to include significant information was Hoge (1953 [1952]), who reported the first specimen of $H$. trivittatus to be collected outside the state of Pará, a juvenile female from Araguacema, Goiás (a locality now in the state of Tocantins). Subsequently, Hoge (1967) reported the species from the federal territory of Amapá, although he did not cite a specific locality nor any specimens on which the record was based.

The two most informative papers to date were those by Cunha \& Nascimento (1978, 1994 [1993]), who examined a combined total of 74 specimens for which they provided ranges of variation in numbers of ventrals, subcaudals, dorsal scale rows, and maxillary teeth. Each paper also included a recognizable photograph of the dorsum of a preserved specimen. Unfortunately, the 1994 paper referred to Guiana (in the sense of Guyana) - as well as Brazil - as being within the geographic range of Helicops trivittatus, but no museum specimen or published reference was cited to justify this statement. In the absence of supporting evidence, it would seem prudent at this time to exclude Guyana from the range of $H$. trivittatus.

Although Helicops trivittatus is readily identified, remarkably consistent in its colour pattern (in marked contrast to most of its congeners), and not involved in any taxonomic controversy, a standardized summary of variation in its meristic and mensural characters seems justified in order that it might contribute to our understanding of intrageneric variation among the species of Helicops (e. g., see Rossman, 2002a, 2002b).

\section{MATERIALS AND METHODS}

In the course of this study, I examined 45 preserved specimens of Helicops trivittatus. Meristic data were recorded for all undamaged specimens, but head length measurements were omitted for female specimens having a snout-vent length less than $425 \mathrm{~mm}$ (and males less than $325 \mathrm{~mm}$ ) to avoid the possible effects of allometric growth. All counts and measurements were made by the methods described in Rossman et al. (1996). Meristic counts included: ventrals (V); subcaudals (SC); supralabials (SL); infralabials (IL); anterior temporals (AT); dorsal scale rows (DSR) at the level of $\mathrm{V} 10$, at midbody, and two $\mathrm{V}$ anterior to the anal plate; and prediastemal maxillary teeth (Mx).

Mensural characters included: tail length/total length $(T / T L)$; head length/snout-vent length $(H / S V L)$; eye diameter/frontal length (ED/FL); frontal length/ parietal length (FL/PL); muzzle length (distance from anterior tip frontal to posterior tip rostral)/frontal length (ML/FL); muzzle width (maximum width of internasal)/ frontal length (MW/FL); anterior frontal width/frontal length (FWA/FL); posterior frontal width/anterior frontal width (FWP/FWA); prefrontal length/internasal length (Prf/ In); combined parietal width/parietal length (CPW/PL); 
maximum supraocular width/posterior frontal width (SoW/ FWP); dorsal/ventral loreal length (LD/LV); loreal height/ ventral loreal length (LHt/LV); ventral loreal length/muzzle length (LV/ML); total nasal length/muzzle length (TN/ML); anterior/posterior chinshield length (ACL/PCL); anterior/ posterior chinshield width (ACW/PCW); anterior chinshield width/length (ACW/L); posterior chinshield width/length (PCW/L). All of the preceding ratios are expressed as percentages. I also recorded width of the outermost dorsal scale row/width of the vertebral row (DSR 1NR) at midbody, but expressed it as an absolute value rather than as a percentage.

\section{REDESCRIPTION OF HELICOPS TRIVITTATUS (GRAY, 1849)}

Holotype: British Museum of Natural History, BM(NH) 1946.1.13.99, an adult female, obtained from the Zoological Society of London.

Type-locality: No locality data known (see Introduction).

Etymology: The species name, trivittatus, is from the Latin, meaning "three stripes or lines".

Definition: A large (maximum recorded SVL $711 \mathrm{~mm}$ ) species of Helicops characterized by having: a maximum of 23 DSR at midbody in females, 21 in males; the single internasal usually (ca. 79\%) separated from the rostral by the paired nasals; a moderate number of $V(q$ 115-129, ô 114-125); a moderately large number of SC (ㅇ 60-66, o 67-80); the dorsum with five narrow longitudinal light stripes; the venter light with two medial rows of broad, black semilunar markings, the same pattern extending onto the underside of the tail.

The combination of five rows of narrow light stripes on the dorsum with a linear pattern of dark spots on the light underside of body and tail readily distinguishes Helicops trivittatus from all other species in the genus.

Variation: Meristic and mensural variation is summarized in Tables 1 and 2. Many characters exhibit sexual dimorphism - some slight (e. g., relative head length, number of V), some pronounced (e. g., number of DSR, number of SC). Males tend to have fewer $\mathrm{V}$ and IL, but more SC and maxillary teeth. Females tend to have a proportionately shorter tail, but a wider DSR 1.

Reduction in the number of DSR from 23 to 21 results from either fusion of rows four and five or loss of one row or the other (in MPEG 13328 it is not clear if row five or six is lost). The point of reduction lies at $52.8 \%$ of total number of ventrals in the four specimens examined for this feature (an apparently anomalous reduction at $11.2 \%$ of $S V L$ in the holotype was omitted from the calculations; the next lowest value was 48.4\%). Reduction from 21 to 19 rows also results from either fusion of rows four and five or loss of one row or the other (in one specimen it is not clear if row five or six is lost, and in another specimen rows five and six are fused). The point of reduction lies at $73.7 \%$ of SVL in seven specimens examined. Reduction from 19 to 17 rows results from the loss of row three or four (point of reduction lies at $94.6 \%$ of total ventrals in four specimens).

Table 1. Individual and sexual variation of selected meristic characters in Helicops trivittatus. Values represent: number of scales (number of specimens - \% of sample).

\begin{tabular}{c|c|c}
\hline Character & M & F \\
\hline Anterior DSR & $21(5-31.3), 22(2-12.5), 23(9-56.3)$ & $23(25-92.6), 24(1-3.7), 25(1-3.7)$ \\
\hline Midbody DSR & $20(1-6.3), 21(15-93.8)$ & $21(12-42.9), 22(1-3.6), 23(15-53.6)$ \\
\hline Posterior DSR & $16(1-6.3), 17(12-75.0), 18(1-6.3), 19(2-12.5)$ & $17(7-25.0), 18(3-10.7), 19(18-64.3)$ \\
\hline Total SL & $16(18-100.0)$ & $16(25-92.6), 17(2-7.4)$ \\
\hline Total IL & $23(2-11.1), 24(15-83.3), 25(1-5.6)$ & $24(16-57.1), 25(7-25.0), 26(2-7.1)$, \\
\end{tabular}

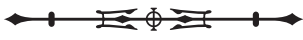


Table 2. Individual and sexual variation of selected meristic and mensural characters in Helicops trivittatus. Values represent mean \pm one SD (range of variation) number of specimens.

\begin{tabular}{|c|c|c|}
\hline Character & Sex & Values \\
\hline \multirow{2}{*}{ Number of $\mathrm{V}$} & M & $120.0 \pm 2.68(114-125) 18$ \\
\hline & $\mathrm{F}$ & $122.4 \pm 3.66(115-129) 27$ \\
\hline \multirow{2}{*}{ Number of SC } & M & $74.7 \pm 3.02(67-80) 16$ \\
\hline & $\mathrm{F}$ & $63.5 \pm 1.60(60-66) 22$ \\
\hline \multirow{2}{*}{$\begin{array}{l}\text { Number of Mx teeth } \\
\text { (prediastemal) }\end{array}$} & M & $21.5 \pm 0.58(21-22) 4$ \\
\hline & $\mathrm{F}$ & $20.5 \pm 0.53(20-21) 10$ \\
\hline \multirow{2}{*}{$\mathrm{T} / \mathrm{TL}$ (as a \%) } & $M$ & $31.9 \pm 2.00(26.8-34.2) 15$ \\
\hline & $\mathrm{F}$ & $26.9 \pm 1.29(24.6-30.3) 21$ \\
\hline \multirow{2}{*}{$\mathrm{H} / \mathrm{SVL}$ (as a \%) } & $M$ & $5.0 \pm 0.61(4.2-6.4) 10$ \\
\hline & $\mathrm{F}$ & $5.2 \pm 0.31(4.7-5.7) 13$ \\
\hline ED/FL (as a \%) & & $49.8 \pm 4.55(43.2-60.5) 45$ \\
\hline $\mathrm{FL} / \mathrm{PL}$ (as a \%) & & $79.6 \pm 6.00(69.1-89.1) 45$ \\
\hline ML/FL (as a \%) & & $59.5 \pm 6.56(47.6-83.0) 43$ \\
\hline MW/FL (as a \%) & & $45.8 \pm 3.90(37.8-54.0) 41$ \\
\hline FWA/FL (as a \%) & & $43.1 \pm 3.95(36.6-51.8) 45$ \\
\hline FWP/FWA (as a \%) & & $110.2 \pm 12.15(91.9-142.0) 44$ \\
\hline Prf/In (as a \%) & & $50.6 \pm 10.17(29.5-83.0) 43$ \\
\hline LD/LV (as a \%) & & $51.5 \pm 8.58(28.0-76.4) 40$ \\
\hline $\mathrm{LH} \mathrm{t} / \mathrm{LV}$ (as a \%) & & $155.8 \pm 21.74(115.8-208.3) 40$ \\
\hline LV/ML (as a \%) & & $35.9 \pm 5.69(23.5-46.2) 39$ \\
\hline TN/ML (as a \%) & & $64.4 \pm 8.29(47.5-81.4) 39$ \\
\hline CPW/L (as a \%) & & $115.1 \pm 6.46(103.1-129.5) 38$ \\
\hline SoW/FWP (as a \%) & & $78.5 \pm 10.63(55.0-100.0) 42$ \\
\hline ACL/PCL (as a \%) & & $124.9 \pm 12.70(105.3-150.8) 44$ \\
\hline ACW/PCW (as a \%) & & $100.8 \pm 9.13(82.7-122.0) 38$ \\
\hline ACW/L (as a \%) & & $43.6 \pm 4.01(34.7-57.1) 35$ \\
\hline PCW/L (as a \%) & & $53.7 \pm 5.60(44.6-67.8) 34$ \\
\hline \multirow{2}{*}{ DSR 1NR } & $M$ & $1.69 \pm 0.13(1.53-1.92) 10$ \\
\hline & $\mathrm{F}$ & $1.81 \pm 0.25(1.53-2.40) 21$ \\
\hline
\end{tabular}

The internasal is clearly in contact with the rostral in four specimens, clearly separated by contact between the opposing nasal scales in 23 specimens, and the four scales meet at a common point in two specimens. The nostril occupies $28 \%$ of the height of the semi-divided nasal scale in the one specimen measured for this character (MCZ 87340), and its ventral margin lies $64 \%$ of nasal height above the ventral suture of this scale.

The ten largest females examined average 555 $\mathrm{mm}$ in SVL (475-711), and the nine largest males average $385 \mathrm{~mm}$ (335-448). Clearly there is significant sexual size dimorphism in this species. Mature males (> 320 mm SVL) have tubercles on the chinshields and anterior infralabials. The in situ hemipenis (three specimens) extends posteriorly to the level of SC 9, dividing at the level of SC 7. The organ lacks calyces and is spinose throughout.

In terms of colour pattern (Figures 1, 2, 3), Helicops trivittatus appears to be one of the least variable species in the genus. The lower half of DSR 1 is cream coloured, like the adjacent venter. The dorsal ground colour ranges from tan (lower sides) or brown to very dark brown (upper back). Very dark brown pigment is present on the anterior half of each scale in DSR 2, 5 or 6, and 9 or 10 (apparently variable position of dark-spotted rows reflects the number of scale rows present at the point of observation). Continuous cream or yellow stripes occur on the upper half of DSR 3-lower half of DSR 4 (largely confined to DSR 3 posterior to DSR reduction point) and on the upper edge of DSR 7 (or DSR 8 anterior to the reduction point). A very narrow yellow or pale tan stripe or line is confined to the scales in the vertebral row.

The dorsolateral light stripes expand slightly on the neck to form a pair of light nuchal spots (separated from the stripe by one tan scale in MPEG 1229), which are more prominent in younger individuals (but are lacking in MPEG 1221, a neonate). A faint hint of paired, light parietal spots is seen in some juveniles. The top and sides of the head are uniformly dark brown, the dark pigment extending ventrally onto the supralabials for about half their height. The lower half of each supralabial is cream colored, but densely speckled with brown pigment.

The chin and throat are cream or white, unmarked except for brown speckling laterally - especially on the mental and infralabials. The venter is cream with two 


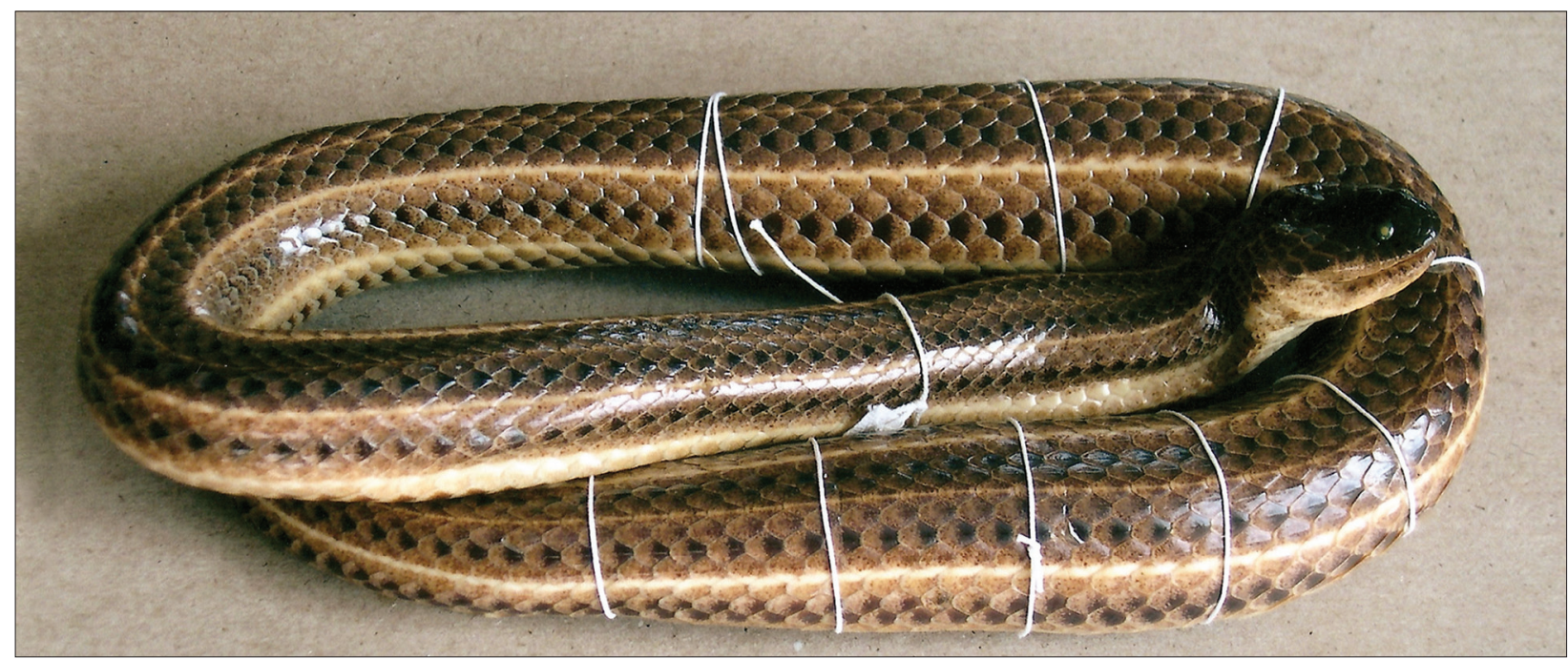

Figure 1. Dorsolateral view of MPEG 8868, an adult (711 mm SVL) female Helicops trivittatus from Belém, Pará, Brazil, showing details of the dorsal color pattern. Photo: D. D. Rossman.

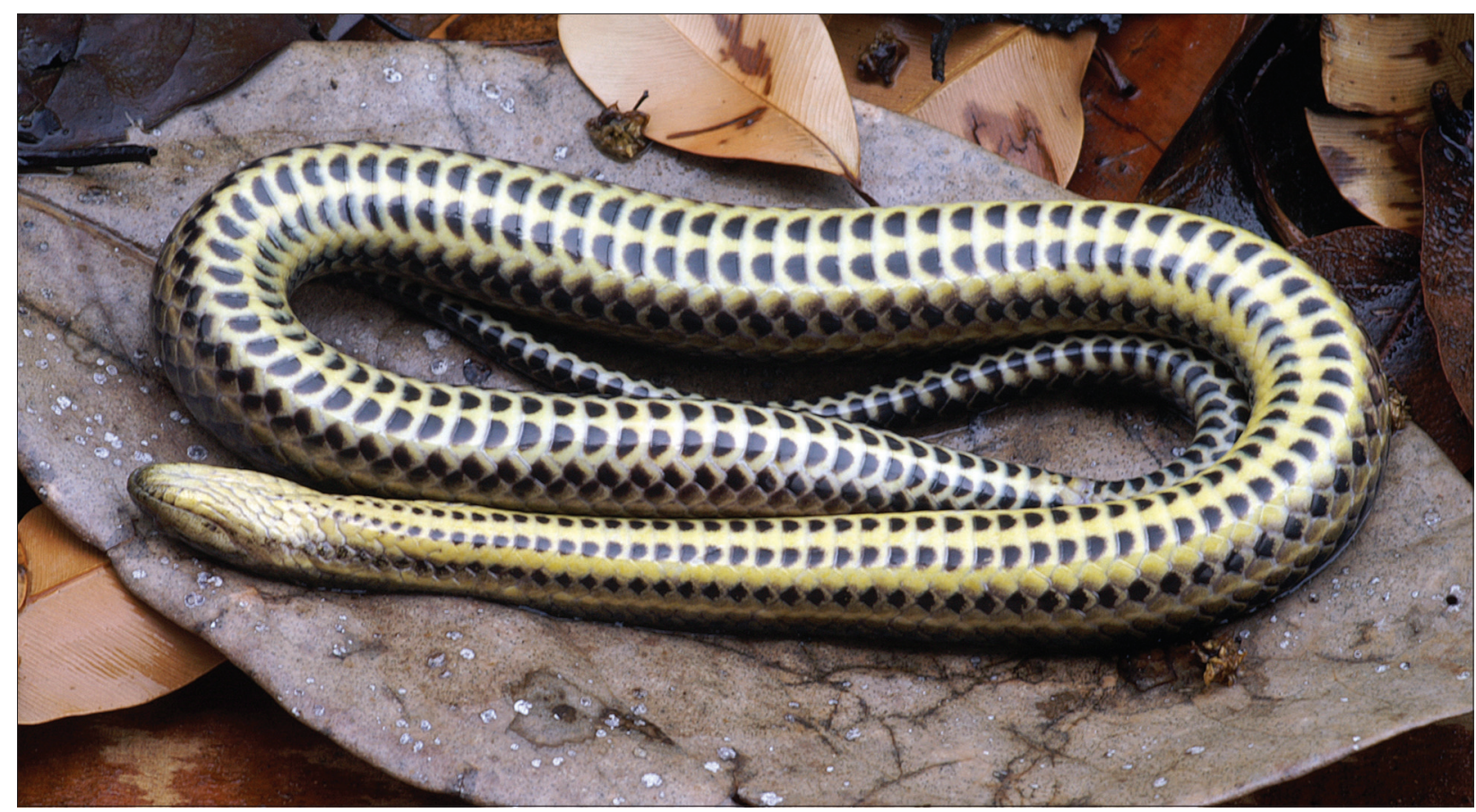

Figure 2. Ventral view of $\mathrm{OMNH} 42321$, an adult (370 mm SVL) male Helicops trivittatus from Caseara, near Rio Cocos, Tocantins, Brazil, showing details of the ventral color pattern. Photo: L. J. Vitt.

uniform rows of very dark brown to black semilunar spots that collectively occupy nearly $80 \%$ of the width of each scale. The anal plate may (MCZ 87340) or may not
(LSUMZ 36608) be marked with dark pigment, but the dark spots on the subcaudals are so extensive that they occupy the anterior $1 / 2$ to $2 / 3$ of each scale.

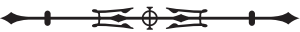




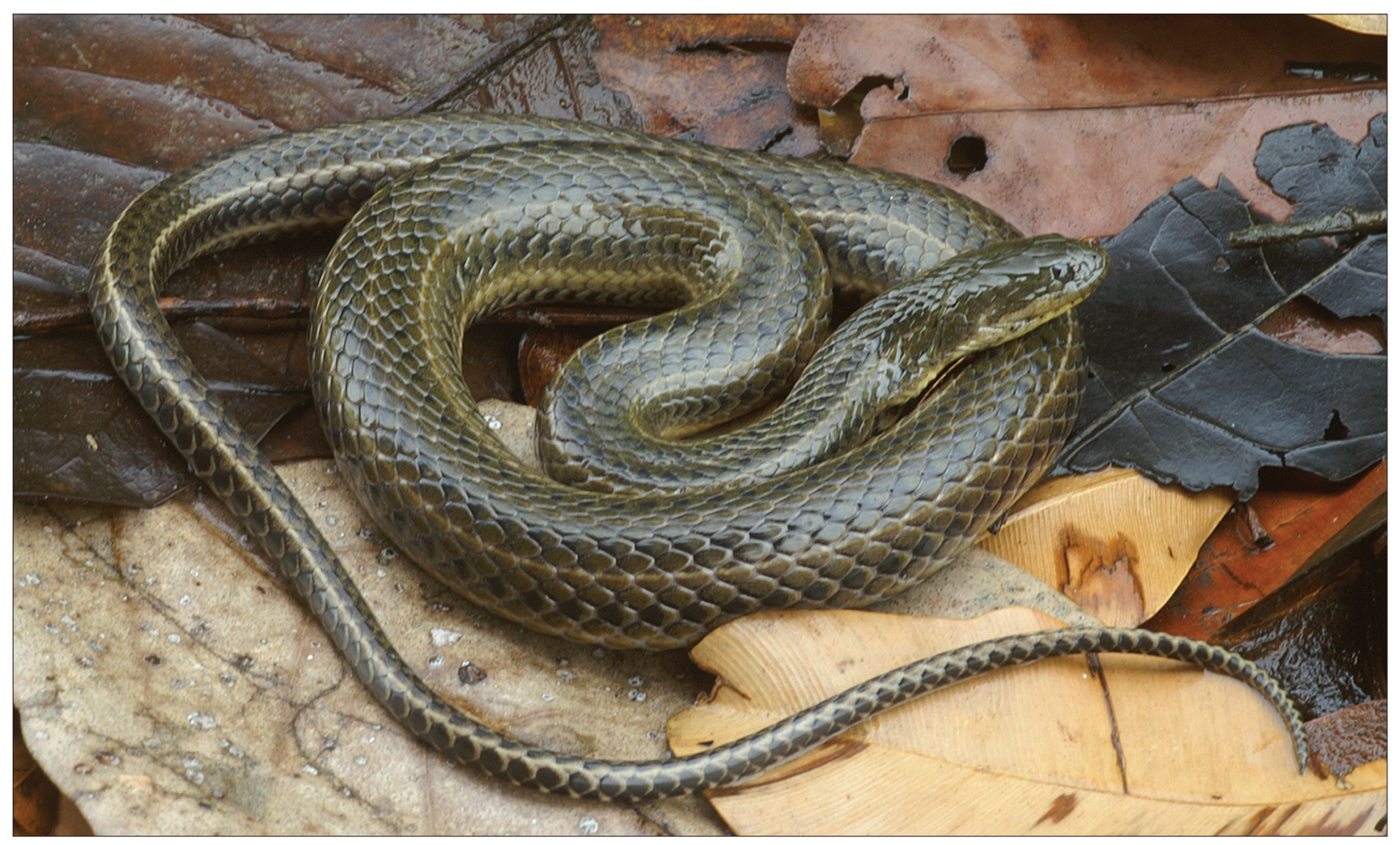

Figure 3. Dorsolateral view of OMNH 42321, an adult (370 mm SVL) male Helicops trivittatus from Caseara, near Rio Cocos, Tocantins, Brazil, showing the dorsal pattern. Photo: L. J. Vitt.

Distribution: North-central Brazil from the upper reaches of the Xingu and Araguaia rivers to the mouth of the Amazon (Figure 4). Known from the states of Amapá, Mato Grosso, Pará, and Tocantins.

\section{SPECIMENS EXAMINED (OR RECORDS CONSIDERED VALID):}

No locality data: BM(NH) 1946,1,13,99 (holotype). "India" [in error]: BM(NH): III.23.2b. Amapá. No specific locality (Hoge, 1967). Mato Grosso. Alto Xingu: MNUFRJ 7784; Parque Indígena do Xingu, Posto Diauarum: LSUMZ36608; Barra do Tapirapés: MZUSP 3815. Pará. Belém: MPEG 135, 734, 759-60, 1097, 1124-25, 1218, 1221, 1229, 8867-68, 18699, 18943, 19297; 5 km E Belém, Utinga: KU 127267. 128099, LSUMZ 44994; Capanema, MPEG 17641-42, 17644, 17647, 17654; município de Melgaço, Floresta Nacional de Caxiuanã [MPEG specimens mentioned in
Maschio et al., 2009], ilha do Marajó, Santa Cruz do Arari [MPEG specimens not seen by me], ilha do Marajó, Ponta de Pedras [MPEG specimens not seen by me], Cachoeira do Arari: MPEG 644, 18013, MCZ 873430; Dom Eliseu, Sítio Bela Vista: MPEG 13391; São Félix, km 11 on PA-222: MPEG 14523; Estrada Mojú-Acará, rio Uba, Povoação do Luso: MPEG 13325-26, 13328, 13331-34; Marabá: MPEG 14523; rio Araguaia, Porto Jarbas Passarinho, Palestina do Pará: MPEG 15216, 15240-44. Tocantins. Araguacema (Hoge, 1953 [1952]); Caseara, near rio Cocos: OMNH 42321.

\section{ACKNOWLEDGMENTS}

I wish to thank the curators at Museu Paraense Emílio Goeldi (MPEG), Belém, the British Museum (Natural History), London (BM(NH)), Museu de Zoologia, Universidade de São Paulo (MZUSP), Museu Nacional, Universidade Federal de Rio de Janeiro (MNUFRJ), University of Kansas

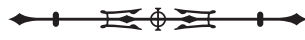




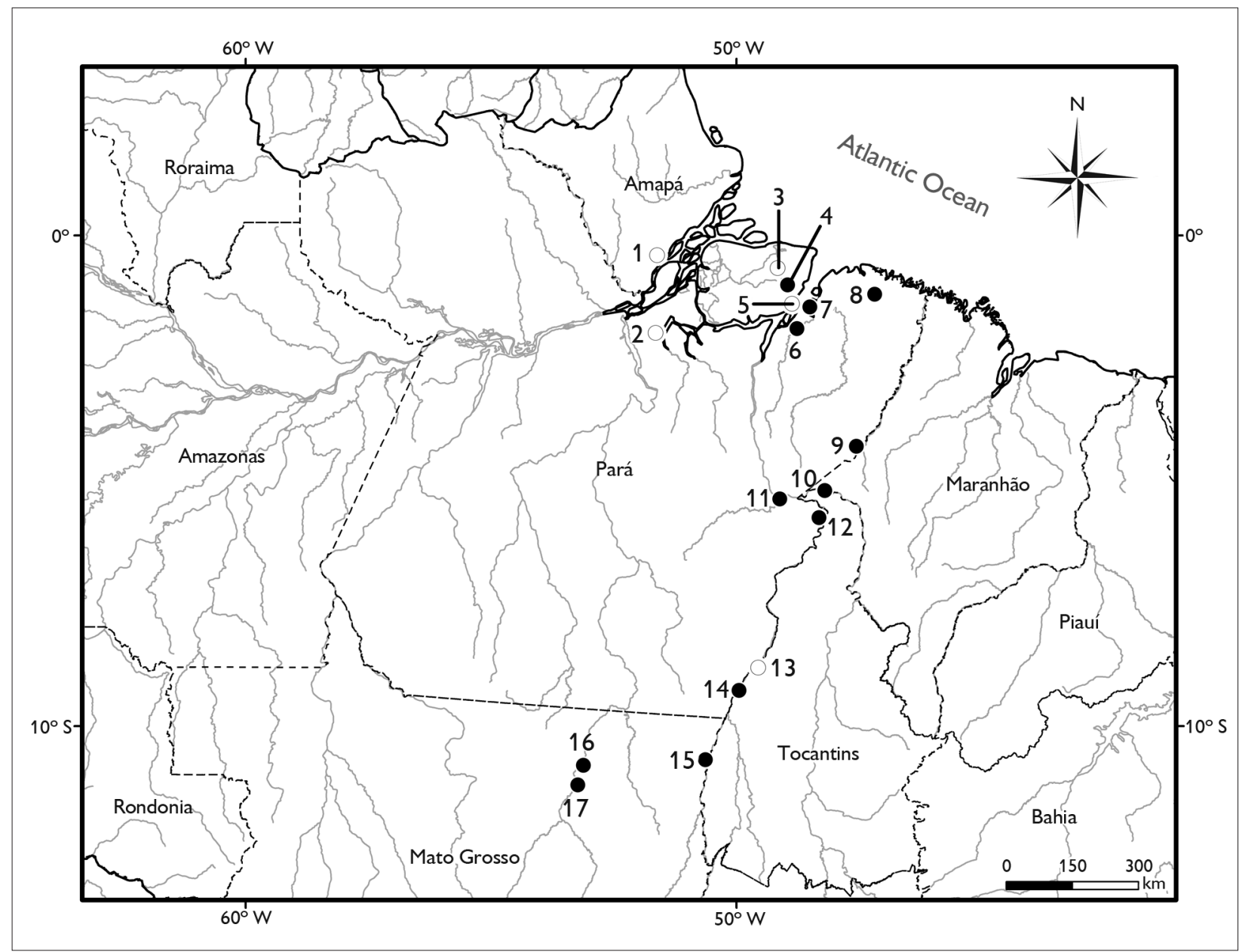

Figure 4. Map of eastern Brazil showing the known distribution of Helicops trivittatus. Solid circles represent specimens personally examined, hollow circles unverified but probably valid records. The localities represented by these circles are as follows: 1) Amapá, no specific locality; 2) Floresta Nacional Caxiuanã; 3) Santa Cruz do Arari; 4) Cachoeira do Arari; 5) Ponta de Pedras; 6) several localities in the greater Belém area; 7) Capanema; 8) Dom Eliseu, Sítio Bela Vista; 9) São Félix; 10) Rio Uba, Povoação do Luso; 11) Marabá; 12) Porto Jarbas Passarinho, Palestina do Pará; 13) Araguacema; 14) Caseara, near Rio Cocos; 15) Barra do Tapirapés; 16) Alto Xingu; 17) Posto Diauarum.

Museum of Natural History, Lawrence (KU), Museum of Natural Science, Louisiana State University, Baton Rouge (LSUMZ), Museum of Comparative Zoology, Harvard University, Cambridge (MCZ), and the University of Oklahoma Museum of Natural History, Norman (OMNH), for the loan of specimens in their care. Marcelo Sturaro of the herpetology laboratory at MPEG generously helped to prepare the distributionmap. For other favours contributing to the completion of this paper, I am also grateful to Teresa
Avila-Pires, Jonathan Campbell, Marinus Hoogmoed, Ana Lucia Prudente, and Laurie Vitt.

\section{REFERENCES}

BOULENGER, G. A., 1893. Catalogue of the snakes in the British Museum (Natural History). v. 1. Trustees of the British Museum (Natural History), London.

CUNHA, O. R. \& F. P. NASCIMENTO, 1978. Ofídios da Amazônia. $X$. As cobras da região leste do Pará. Publicaçoes Avulsas do Museu Paraense Emílio Goeldi 31: 1-128.

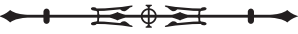


CUNHA, O. R. \& F. P. NASCIMENTO, 1994 [1993]. Ofídios da Amazônia. As cobras da região leste do Pará. Boletim do Museu Paraense Emílio Goeldi, série Zoologia 9: 1-191.

GOMES, J. F., 1918. Contribuição para o conhecimento dos ofídios do Brasil - III. 1. Ofídios do Museu Paraense. Memórias do Instituto Butantan 1: 57-77.

GRAY, J. E., 1849. Catalogue of the specimens of snakes in the collection of the British Museum. Trustees of the British Museum, London.

HOGE, A. R., 1953 [1952]. Notas herpetológicas. 1ª Contribuição ao conhecimento dos ofídios do Brasil Central. Memórias do Instituto Butantan 24: 179-214.

HOGE, A. R., 1967. Serpentes do Território Federal do Amapá. Atas do Simpósio sôbre a Biota Amazônica 5(Zoologia): 217-223.

MASCHIO G. F., M. C. SANTOS-COSTA \& A. L. C. PRUDENTE, 2009. Comunidade de serpentes da região de Caxiuanã com avaliação da eficiência dos métodos de captura. In; P. L. B. LISBOA (Ed.): Caxiuanã. Desafios para a conservação de uma Floresta Nacional na Amazônia: 589-603. Museu Paraense Emílio Goeldi, Belém.
ROSSMAN, D. A., 2002a. Variation in the xenodontid water snake Helicops scalaris Jan, and the status of $H$. hogei Lancini. Occasional Papers of the Museum of Natural Science (78): 1-18.

ROSSMAN, D. A., 2002b. Morphological variation in the endemic Colombian water snake, Helicops danieli Amaral, 1937 (Serpentes: Xenodontidae). Revista de Academia Colombiana Ciencias 26: 589-594.

ROSSMAN, D. A., N. B. FORD \& R. A. SEIGEL, 1996. The Garter Snakes: Evolution and Ecology: i-xx, 1-332. University of Oklahoma Press, Norman.

ROSSMAN, D. A. \& N. J. SCOTT, 1968. Identity of Helicops wettsteini Amaral (Serpentes: Colubridae). Herpetologica 24: 262-263.

Recebido: 01/10/2009

Aprovado: 08/09/2010

Responsabilidade editorial: Marinus Hoogmoed 